\title{
Transitional Justice in Taiwan: An Austrian Perspective
}

\author{
Christian Schafferer*
}

Sixty years ago, the Nationalist Chinese Army brutally killed several thousand civilians in Taiwan. After the massacre, the Chinese Nationalists under Chiang Kai-shek and his son Chiang Ching-kuo continued to rule Taiwan until 1988. During the Chiang era, tens of thousands of civilians were persecuted, tortured and killed. After almost twenty years of democratisation, none of perpetrators has been prosecuted. Every attempt to discuss the issue of transitional justice in public ends in a justification of the atrocities and a glorification of the prime perpetrators. Taiwan's achievement in the area of transitional justice is deplorable and its intellectual discourse a threat to the future human rights situation in the region. It constitutes a threat because it overtly emphasizes economic growth and completely writes off the necessity of humanity.

As an Austrian citizen who has been told since early childhood that crimes against humanity are no peccadilloes (Kavaliersdelikte), the ongoing ignorance and belittlement of the crimes committed by the Nationalists (KMT) are completely unacceptable and outrageous.

In this paper, I would like to discuss Taiwan's transitional justice from an Austrian perspective. The first part of the paper gives an overview of the most important laws that were passed immediately after the war as to deal with Austria's dark past, that is the Nazi dictatorship (1938-1945). The second part looks at the legal provisions requesting the prosecution of those questioning the existence of the Nazi crimes or glorifying the Nazi regime. The third part is an analysis of the current discourse in Taiwan on transitional justice, and the last summarizes the main features of transitional justice in Taiwan and Austria, and concludes with several normative policy suggestions.

\section{Transitional Justice (1945-1957)}

In 1938, Austria became part of the Third Reich and the Republic of Austria ceased to exist. Immediately after the Second World War, Austria regained independence. In April 1945, an interim coalition government, including socialists, conservatives and communists, was formed. One of the major aims of the new government was to destroy the Nazi party (NSDAP) and all its related organizations, to clean the entire state apparatus from the Nazis (Entnazifizierung), and to prosecute the perpetrators. As to achieve these aims, several special laws were passed. The two most important were the Verbotsgesetz (Prohibition Act) and the Kriegsverbrechergesetz (War Criminal Act).

Christian Schafferer is an associate professor at the Department of International Trade, The Overseas Chinese Institute of Technology (Taiwan) and a visiting professor at the Department of Political Science, Meiji University (Japan). 


\subsection{Verbotsgesetz (VG)}

The Verbotsgesetz was passed in August 1945. ${ }^{1}$ The law was designed to prevent the re-occurrence of a Nazi state and to provide a legal framework under which Nazi crimes could be prosecuted.

The very first article of the law stipulated that the NSDAP and all its related organizations be dissolved and that all their property be transferred to the State. Moreover, any attempt to reestablish such organizations was declared a criminal act (Article 1). Violators faced severe sentences including the death penalty (Article 3).

According to the law, all members of the NSDAP and its related organizations had to register with the authorities (Article 4). The registration was necessary as to start the process of denazification. In July 1947, the government announced that based on the information gathered through the registration process, a total of 960 people had been removed from high-ranking positions in the state and private sector, some 70,000 out of 300,000 civil servants had been suspended and another 36,000 employees had lost their jobs in the private sector. ${ }^{2}$

The law in its original form had several flaws. For example, it allowed members of the NSDAP who were not actively involved in the Nazi movement to petition for exemption. This regulation caused serious bureaucratic problems, since over 85 percent of the Nazis claimed that they had not been active members. A further problem was that the law did not distinguish between those who were key figures in the Nazi movement and those who held lower positions in the Nazi hierarchy. All Nazis were thus equally sanctioned regardless of the scope of their involvement. ${ }^{3}$

In 1947, the VG was thus revised and another law, the Nationalsozialistengesetz, implemented. The latter law defined the criminal offences contained in the Verbotsgesetz in a more detailed way, replacing the general offence by a number of provisions.

Moreover, the revised VG now made a distinction between those who held key positions (Belasteten) and those who were 'mere followers' of the Nazi regime (Minderbelasteten). A year after the law was passed, the number of Belastete accounted for 43,468 (8 percent of all registered Nazis) and the number of Minderbelastete was as high as $487,067 .{ }^{4}$ The 1947 revision extended the compulsory registration from NSDAP members to those who were not members but actively supported the Nazi regime (Article 4, VG). One of the consequences of the revisions and the Nationalsozialistengesetz was that another 22,000 public servants were suspended. If compared with the number of public servants who were in office in 1945, one third lost their jobs because of the VG. ${ }^{5}$ Suspension was only one of the various so-called atonement measures (Sühnefolgen) registered supporters of the NSDAP faced. According to the VG and the Nationalsozialistengesetz, ranking members of the NSDAP and other highly active supporters of the regime (the so-called Belasteten) had to accept the following atonement measures (Article 18, VG):

1. Special taxes: 20 percent in addition to their income tax for five years

2. Compensation: 20 to 70 percent of their capital has to be handed over to the state

3. Deprivation of civil rights: barred from candidacy in national and local elections for lifetime, barred from voting in national and local elections for 5 years, barred from being a member of a political party for five years

4. Barred from taking positions in universities and other public institutions for lifetime

\section{StGBl. Nr. 13/1945}

Winfried Garscha R., "Entnazifizierung und gerichtliche Ahndung von NS-Verbrechen," in NS-Herrschaft in Österreich, ed. by Emmerich Talos, Ernst Hanisch, Wolfgang Neugebauer and Reinhard Sieder (Wien: Oebv, 2000), 858 .

Garscha, Entnazifizierung, 858; Dieter Stiefel, Entnazifizierung in Österreich (Wien: Europaverlag, 1981).

4 Garscha, Entnazifizierung, 859.

5 Garscha, Entnazifizierung, 860. 
The atonement measures of the so-called Minderbelasteten included:

1. Special taxes: 10 percent in addition to their income tax for three years

2. Compensation: 10 to 40 percent of their capital has to be handed over to the state

3. Deprivation of civil rights: barred from candidacy in national and local elections for 5 years

4. Barred from taking positions in universities and other public institutions, but he or she may apply to government for exemption

The law also requested the establishment of special courts (Volksgerichte) that should exclusively deal with crimes mentioned in the Verbotsgesetz and the Kriegsverbrechergesetz (Article 24-26, VG). In August 1945, the first such court was set up in Vienna and soon three others throughout Austria. Verdicts reached by the courts were final, i.e. there was no legal remedy. Sentences were immediately carried out. The Supreme Court (Oberster Gerichtshof, OGH) could, however, void the judgment and request a retrial with different judges if it observed major discrepancies in the way the Volksgericht handled the case. ${ }^{6}$ Only those who had no past record of any affiliation with the Nazi regime could become judges at the Volksgerichte. In 1955, the Volksgerichte were closed. Ordinary courts took over the duty of convicting the perpetrators. Between 1945 and 1955, the Volksgerichte held about 90,000 pre-trial hearings. There were some 28,000 indictments, and in about 25,000 cases main trials took place. About 90 percent of the main trials were held before 1950. Approximately 70 percent of the 20,000 people standing main trial were found guilty. ${ }^{7}$ As illustrated in Table 1, almost half of the trials took place at the Volksgericht Vienna. On the average, every second indictment let to a conviction.

Table 1: Cases tried by the Volksgerichte (1945-1955)

\begin{tabular}{llllll}
\hline Volksgerichte & Vienna & Graz & Linz & Innsbruck & Total \\
\hline Indictments & 13,561 & 6,698 & 5,958 & 1,931 & 28.148 \\
Convictions & 6,701 & 3,873 & 1,993 & 1,040 & 13,607 \\
Ratio \% & 49.41 & 57.82 & 33.45 & 53.86 & 48.34 \\
\hline
\end{tabular}

Source: Dokumentationsarchiv des Österreichischen Widerstandes, "Verfahren vor österreichischen Volksgerichten," http://www.doew.at/thema/vg/vg.html\#wien (accessed December 17, 2006).

\subsection{Kriegsverbrechergesetz (KVG)}

In June 1945, the interim government passed the Kriegsverbrechergesetz (KVG). The law was necessary for various reasons. Existing laws, for instance, did not cover crimes against humanity, such as denunciation and deportation. Moreover, the German Criminal Code addressed other offences such as murder and personal injury, but the sentences were considered too lenient given the nature of the crimes the Nazis had committed. ${ }^{8}$ The interim minister of justice referred to the KVG as an exceptional law to deal with exceptional crimes. ${ }^{9}$ Some parts of the law were considered retroactive, which caused criticism among legal experts. In general, retroactive legislation is considered a violation of legal principles (nullum crimen, nulla poene sine lege). As to the KVG, however, the majority of jurists did neither see a legal nor a moral problem with the retroactivity of the KVG. One group of legal theorists argued that at the time the law was passed and in force no equal or higher

\footnotetext{
Garscha, Entnazifizierung, 861.

Dokumentationsarchiv des Österreichischen Widerstandes, "Verfahren vor österreichischen Volksgerichten," http://www.doew.at/thema/vg/vg.html\#wien (accessed December 17, 2006).

8 Garscha, Entnazifizierung, 864.

$9 \quad$ Rundbrief, Juni 1999, p. 9.
} 
legal norm existed that would have prohibited or restricted retroactive legislation. Other theorists pointed out that the Nazis themselves had amended the German Criminal Code (Article 2, RstGB) in 1935 allowing for the retroactive prosecution for any action that should deserve punishment according to the "sound feelings of the people." ${ }^{10}$ In the Declaration of Independence of 27 April 1945, the interim government noted that the Nazis ought to be treated under the same exceptional legal framework that they had forced upon the people of Austria. ${ }^{11}$

The law covered the following offences:

1. War crimes (Kriegsverbrechen)

2. War mongering (Kriegshetzerei)

3. Agony and maltreatment (Quälereien und Misshandlungen)

4. Transgression of humanness and human dignity (Verletzungen der Menschlichkeit und Menschenwürde)

5. Expropriation and forced resettlement (Vertreibung aus der Heimat)

6. Immoral enrichment (Missbräuchliche Bereicherung), and

7. Denunciation (Denunziation).

Sentences depended on the type of crime committed, the role of the accused in the crime and on whether the crime was systematic or not. The law demanded lighter sentences in cases where the accused acted on instruction. The law explicitly ruled that perpetrators could not claim their innocence by stating that they had just executed orders. Amnesty was only granted in cases where the perpetrator could prove that he/she had committed the crime against her/his own will (Befehlsnotstand). None of the accused in the post-war trials could provide sufficient evidence to back such a claim, though. ${ }^{12}$

Tougher sentences had to be given to those who gave orders and to those who committed the same crime repeatedly. The law stipulated that perpetrators had to be sentenced to death when they had committed the crimes systematically.

The law defined war crimes as offences that contradict the natural requirements of humanity and violate the generally accepted principles of international law. Article 1 stated that all government members during the Nazi period and all other high-ranking members of the NSDAP were war criminals who had to be sentenced to death. There was no evidence for their actual involvement in a crime necessary, since it was believed that whoever had held such positions in the Nazi hierarchy would have undoubtedly been involved in the planning and ordering of the Nazi atrocities (praesunito iuris ac de jure). ${ }^{13}$

Article 2 of the law made war mongering a criminal offence. A warmonger was defined by the law as someone who tried through means of propaganda to make the masses belief that the war was justified and the only way for the German race to survive as a nation. The minimum sentence was ten years. When the perpetrator used force to convince others about the necessity of the war, he or she had to be sentenced to death.

Article 3 of the law requested the prosecution of those who committed acts of agony and maltreatment. This paragraph of the law targeted those party and state officials who (mis)used their positions to attack opponents of the NS dictatorship. Prosecution did not require physical harm; the exertion of mental pain was sufficient. Whoever verbally attacked opponents of the NS regime and created an atmosphere of fear and terror had to face a minimum prison sentence of five years. In

\footnotetext{
Rundbrief, Juni 1999, p. 9.

StGB1. 1/1945

Garscha, Entnazifizierung, 515.

Rundbrief, Juni 1999, p. 14.
} 
cases where the victim's health had deteriorated as a consequence of the maltreatment, the perpetrator had to serve prison terms between ten and twenty years. The death sentence was passed when the maltreatment had caused the victim's loss of life or when the maltreatment (apart from the mental/physical pain) severely violated the basic principles of humanity.

Article 4 of the law addressed offences that were considered transgressions of humanness and human dignity. According to the Austrian Supreme Court ruling of July 1948, such offences included any action that one would even under the most primitive assumptions of humanity consider inhuman. ${ }^{14}$ The minimum sentence was one-year imprisonment. The perpetrator was sentenced to death when the transgression resulted in the victim's loss of life.

The law (Article 5 and 6) required similar sentences in cases where supporters of the NS regime were convicted of crimes such as expropriations, forced resettlements, and immoral enrichments.

Article 7 of the law dealt with cases of denunciation. According to the law, whoever inflicted harm on an individual with the intent to support the NS regime or because of other contemptuous motives had to face prison terms ranging from one to five years. The sentence was increased to ten years when (a) the informer deliberately made false accusations, (b) the victim's occupational advancement or livelihood had been endangered because of the denunciation, (c) the perpetrator and victim had been in a special relationship (such as marriage), or (d) the denunciation had been made as to serve the informer's own interest. Moreover, the informer was sentenced to life imprisoned when the victim had been sentenced to death because of his or her accusations.

The law specifically targeted those informers who deliberately submitted reports to the authorities for personal gains and those who did so because of their support for the Nazis. It was, thus, legal practice at that time to prosecute those informers who reported violations of the special laws passed by the NS government, such as the laws governing the prohibition of new political parties, underground radio stations, and treason. However, those who reported violations of laws that had existed before the NS government were exempted from prosecution when the NS government had not significantly increased the penalty for such offences. ${ }^{15}$

During the post-war years, some 10,015 trials were held because of violations of the KVG. About 60 percent of the cases dealt with denunciation. ${ }^{16}$

\section{Transitional Justice after 1957}

The KVG was in force until 1957, when the Amnesty Act (Amnestiegesetz) was passed. The government at that time was of the opinion that after more than ten years of prosecution, the focus of their anti-Nazi efforts should shift from prosecution to prevention. The KVG was thus abolished, but the VG not. As a matter of fact, the VG is still in force today. Trying to re-establish NS organizations, contacting or financing such organizations, or producing propaganda material is a criminal offence under Article 3 of the law and carries a minimum prison sentence of ten years. If the offender or the action is particularly dangerous, the penalty is life imprisonment. Being a member of organizations that pursue the aims of the NSDAP carries a minimum sentence of five years imprisonment. Moreover, anyone who denies, grossly trivializes, approves of or seeks to justify the NS

14 OGH 3.7.1948, EvB1. 909/48. In this case, members of the SS claimed that their arbitrary house search was not a transgression of humanness and human dignity.

15 Heinrich Gallhuber and Eva Hopfer, "Die Einzelnen Bestimmungen des KVG," Justiz und Erinnerungen, no. 4 (2001): 33. See also Guido Tiefenthaler, Denunziation während der NS Herrschaft im Spiegel der Volksgerichtsprozesse (Wien: Universität Wien, Diplomarbeit, 1995.

16 Heimo Halbrainer, "Der Angeber musste vorhersehen, dass die Denunziation eine Gefahr für das Leben des Betroffenen nach sich ziehen werde," in Holocaust und Kriegsverbrechen vor Gericht ed. Thomas Albrich, Winfried R. Garscha and Martin F. Polaschek (Innsbruck: Studienverlag, 2006), 230. 
genocide or other NS crimes against humanity in a publication, broadcast or other media or in any other public manner accessible to others faces imprisonment between one and ten years.

The law is not only written on paper but also enforced. Several hundred offenders have been charged and found guilty during the last few years. The most prominent case in recent history involved the British historian David Irving, who denied the existence of the Nazi crimes in two speeches held in 1989. On entering Austria in 2005, he was arrested, charged under the VG and served a one-year prison term.

David Irving and some right-wing supporters have claimed that the law clearly violates the freedom of expression. By passing the law, the Austrian government made it clear that the Nazi crimes were proven historical facts that need not be proven again in court. Moreover, the European Court of Human Rights ruled in several instances that the provisions of the VG were in line with the European Convention of Human Rights. Article 17 of the Convention explicitly grants governments the right to protect their democratic values and institutions. ${ }^{17}$

The VG has become part of Austrian history and it should convey the message that no one has the right to belittle the numerous crimes against humanity the Nazi regime had committed. It should also give respect to the victims, especially to those who survived the terror of the regime. It is inhuman to glorify and trivialize the NS atrocities in front of those who suffered and still suffer from the psychological and physical pain that had been caused by exactly these atrocities. Denial and belittlement do not contribute to a more human society. On the contrary, they bring us closer to those who committed the atrocities.

\section{Taiwan's Transitional Justice}

I have observed Taiwanese politics for over ten years. Very often I have felt deeply depressed about the way politicians, scholars and other intellectuals deal with the past atrocities committed by the KMT authorities. Since the 2004 presidential election campaign, I have kept asking myself how deep the KMT and its supporters could possibly fall. After all, there must be and end to their contemptuous behaviour. It seems, however, as if there always were even lower levels of inhumanity. In the following, I would like to discuss some of the most depressing attitudes of Taiwan's intellectuals towards transitional justice.

In March 2004, the KMT presidential campaign headquarters in Taichung distributed posters that likened President Chen Shui-bian with war criminal Saddam Hussein and terrorist Bin Laden. ${ }^{18}$ Although it is completely incomprehensible what Bin Laden and Saddam Hussein have to do with President Chen Shu-bian, the KMT insisted that their posters were extremely inventive and refused to stop their circulation. The chief campaign strategists at the KMT headquarters in Taipei considered the posters a belittlement of President Chen's real character and decided to look for a more appropriate comparison. Soon, the people of Taiwan were taught in newspaper advertisements that President Chen Shui-bian resembled Adolf Hitler. ${ }^{19}$ The ad quoted an international organisation (Freedom House) as saying that under President Chen corruption had increased and democracy deteriorated. Apart from the fact that the organisation was intentionally misquoted, the comparison with Hitler is far beyond the limits of freedom of expression. It constitutes an inhuman act because

17 Felix Mueller, Das Verbotsgesetz im Spannungsverhältnis zur Meinungsfreiheit: Eine Verfassungsrechtliche Untersuchung (Wien: Verlag Österreich, 2005)

18 I believe that a comparison between Chiang Kai-shek and Saddam Hussein would have been more in line with historical facts. The two posters can be viewed at: http://www.eastasia.at/vol3_1/binl.htm and http://www.eastasia.at/vol3_1/saddam.htm

19 The ad can be viewed at: http://www.eastasia.at/vol3_1/ad1.htm 
the comparison belittles (if not even negates) the crimes committed by the Nazis. Moreover, it ridicules the mental and physical pain the victims have suffered. ${ }^{20}$

Unfortunately, the belief that President Chen Shui-bian is Taiwan's Hitler is not only shared by the KMT leadership but also by a large number of intellectuals in Taiwan. One of the most prominent examples is Huang Kuang-kuo (Huang Guang-guo), a professor of psychology at National Taiwan University. Huang branded Chen Shui-bian a populist and likened him and the DPP with the Nazis in his book Populism and the End of Taiwan: A Chronology. ${ }^{21}$ Huang Chi-hsian (Huang Zhi-xian), another prominent intellectual, wrote more explicitly about the close resemblance of Adolf Hitler and Chen Shui-bian in her book Shuddering Future: Dismantle Taiwan's New Dictatorship. ${ }^{22}$ The book cover shows Chen Shui-bian's silhouette and a swastika-style party emblem of the DPP. ${ }^{23}$ The reader could also gather from the cover that it was highly recommended by distinguished intellectuals such as writer and social critic Nan Fang-shuo. Whenever I showed the book to foreign friends, they would be deeply shocked about the primitiveness and stupidity of such publications. The fact that books like those authored by Huang Kuang-kuo and Huang Chi-hsian are highly recommended and sold in almost every bookstore in Taiwan is even more alarming.

Soon after the 2004 presidential election soap opera, we could observe the so-called new democracy movement. And there was James Soong (Song Chu-yu) standing on a huge platform in front of the Presidential Palace. He was surrounded by tens of thousands of cheering anti-Chen activists. Soong used this opportunity to publicly claim that he was Taiwan's true democracy fighter. He backed up his claim by quoting former US President Abraham Lincoln. But, where had James Soong been several decades earlier? Had he not held key positions in the KMT and the government during the period of White Terror? Had he himself not played a crucial role in the crackdown of the opposition movement? Despite his anti-democratic past, he portrait himself as the protector of Taiwan's democracy, lavishly quoting Lincoln. And the media discovered in him a new hero, the leader of a new democracy movement that would bring back justice and re-establish democratic order.

Almost two years later, President Chen Shui-bian and his wife were told to be high-profile criminals who had robbed the Republic of China's treasury. Now the time seemed ripe for all the unemployed democracy activists to call for a revival of the so-called new democracy movement. Former opposition leader Shih Ming-teh (Shi Ming-de) emerged as the new leader of the movement, replacing retired part-time activists James Soong and Lien Chan. He dug out his political marketing tools of the late 1970s and modified the fist emblem he used in the 1978 parliamentary election campaign. Soon, the streets of Taipei were crowded with people giving President Chen Shui-bian the thumbs down and yelling the phrase abian xiatai, meaning down with President Chen Shui-bian. In the 1970s, Shih Ming-teh described former President Chiang Ching-Kuo (Jiang Jing-guo) and his KMT as criminals, but now he considered them their compatriots. When Shih Ming-teh's Red Movement began to cover the island and the ruling Democratic Progressive Party (DPP) asked its supporters to show unity, Shih Ming-teh attacked President Chen Shui-bian by saying that the mass mobilisation of supporters had been something Hitler had played with and that we all knew what the consequences of such actions had been. But why did Shih Ming-teh compare President Chen with Hitler not with Chiang Kai-shek (Jiang Jie-shi) or Chiang Ching-kuo? Highly respected and influential writer Long Ying-tai answered this question in full when she wrote in a newspaper commentary that Chen Shui-bian had been the only criminal and most disgraceful president in the entire history

20 The same holds for the posters distributed by the KMT in Taichung.

21 Huang Guang-guo, Populism and the End of Taiwan: A Chronology [mingcui wang tai ji] (Taipei: Democratic Action Alliance, 2004).

22 Huang, Zhi-xian, Shuddering Future: Dismantle Taiwan's New Dictator [zhanli de weilai: jiegou taiwan xin ducai], revised edition (Taipei: Miluo, 2004).

23 The cover can be viewed at: http://www.eastasia.at/dpp_hitler.htm. 
of the Republic of China. ${ }^{24}$ Her commentary truly reflects the thinking of the entire KMT leadership and its supporters.

In 2006, the 2-28 Memorial Foundation released a research report on the responsibility of the 228 Massacre. ${ }^{25}$ The report concluded that Chiang Kai-shek was the prime perpetrator of the massacre. Unsurprisingly, the KMT and its supporters did not share that view. Consequently, John Chiang (Jiang Xiao-yan), a descendent of Chiang Kai-shek and a high-ranking KMT member, filed a libel suit against the authors of the report. Chiang repeatedly stated that some local officials had caused the incident. He denied that the KMT or even Chiang Kai-shek had any responsibility for the massacre. Chiang is not alone with this claim. KMT Chair Ma Ying-jeou (Ma Ying-jiu) has voiced the same opinion on several occasions. The strategy of the KMT is to belittle the massacre and to shred off the responsibility for it. This goal is obtained by 'educating' the general public about the 'truth.' In a recent documentary sponsored by Ma Ying-jeou's Taipei City Government's Department of Cultural Affairs, for instance, the massacre is portrait as the mere result of language barriers.

The KMT's diffusion strategy also includes the holding of conferences on the massacre, annual visits to victims, and occasionally some words of apology. Such apologies are vague and far from being honest, though. How honest can John Chiang be? Did he not fight court battles to obtain the right to use the family name of his father, former dictator Chiang Ching-guo? How serious can Ma Ying-jeou be when he protects John Chiang and glorifies his ancestors? Chiang Ching-kuo had people killed and tortured, and his father had even been worse. He was a mass murderer, a textbook example of a ferocious dictator. He not only had civilians killed, he also killed them with his own hands. The KMT itself has a history of torture, extortion, rape, drug trafficking, arson, bribery, and murder. These are historical facts! According to moderate estimates, Chiang Kai-shek and his KMT brutally killed about ten million civilians on the mainland. ${ }^{26}$ The Encyclopaedia of Genocide and Crimes Against Humanity writes that Chiang Kai-shek:

ordered the arrest and execution of hundreds of communists and trade unionists in Shanghai in April 1927 [...] From 1927 to 1949, Chiang's troops used murder, torture, and other brutal tactics to wipe out the communists. In one campaign [...] the KMT killed or starved to death as many as one million people [...] They executed prisoners, communist sympathizers, and collaborators. They looted, raped women, and gunned down civilians as they passed through villages and towns. [...] The Nationalist government, corrupt and greedy, did little to ease the suffering from famine, drought, and war. It was responsible for perhaps as many as two million famine deaths during its rule. An estimated four million men died during forced conscription alone. In one battle, to deter the advancing Japanese troops, the Nationalists opened the Yellow River dikes, drowning at least 440,000 people in the ensuing flood. ${ }^{27}$

The 2-28 Massacre is only a very, very small part of the whole picture of horror and destruction. Do John Chiang and Ma Ying-jeou seriously want to claim that Chiang Kai-shek, Chiang Ching-kuo and their own party were not responsible for the thousands of crimes against humanity that had been committed during their dictatorships? Who set up and controlled the network of terror? Who instructed the torture of civilians? Who ordered the shootings of anyone who voiced his or her opinion against the regime? Do Chiang and Ma really mean to say that some local officials and language barriers were to blame for these widespread and systematic human rights abuses? With such

24 China Post, 24 August 2006, A3.

25 Li, Yan-Xian, Yang Zhen-long and Zhang Yan-Xian ,eds., Report on The Responsibility for the 228 Massacre [ererba shijian zeren guishu yanjiu baogao] (Zhonghe: 228 Memorial Foundation).

26 Rummel, R. J., Death by Government (Transaction: New Brunswick, 1994).

27 Encyclopaedia of Genocide and Crimes Against Humanity, ed. Dinah L. Shelton (Thomson: Farmington Hills, MI, 2005), 170-71. 
ferocious statements the KMT leadership engages in historical revisionism as David Irving did with his book Hitler's War. ${ }^{28}$

But, how about Ma Ying-jeou's own involvement in the KMT atrocities? In 1998, a group of intellectuals claimed in a newspaper advertisement that Ma Ying-jeou worked as a spy for the KMT. ${ }^{29}$ His activities included the filing of reports on the anti-KMT activities of his fellow students at Harvard University. Ma has ever since denied such claims. Others defended Ma by saying that he had only done his duty. Several years later, the same allegations were made against Jason $\mathrm{Hu}$ (Hu Zhiqiang), another high-ranking KMT member and incumbent mayor of Taichung. Jason Hu spent ten years in the UK pursuing his studies at Oxford University. He, too, denied any spy activities. I wonder how naïve somebody must be to believe that both of them did not pass on any single piece of information about the activities of their fellow citizens. Both were members of the KMT, both received benefits from the KMT for their efforts. Jason Hu even used his ten years as a party worker in the calculation of his public official retirement benefits. If people did indeed face reprisals because of their denunciations then both were accessory to the crimes against humanity the KMT and its related organisations had committed. They would be responsible for such crimes because they were fully aware of the inhuman consequences of their actions. Moreover, they were both neither legally, physically nor mentally forced to make the denunciations. Thus, they cannot excuse themselves by saying that they only did their duties. ${ }^{30}$ Even if both 'merely' made propaganda for the KMT during their student years, they could still be considered criminals under the principle of praesumito iuris ac de jure, when taking into account that both of them had held higher positions in the KMT and government hierarchy during the martial law period. Of course, Ma and $\mathrm{Hu}$ were not the only informers. But what is distressing is the fact that they are highly respected for what they have done and that their crimes are belittled if not even justified-at home as well as abroad.

Ma Ying-jeou has repeatedly spoken of a new KMT, a party with high moral standards, a party that fights corruption and so forth. But where are these high standards? Has the top leadership of the KMT distanced itself from Chiang Kai-shek and Chiang Ching-kuo? Has the KMT distanced itself from itself? Have the former KMT officials be sanctioned? On the contrary, they have been declared heroes and Chiang Kai-shek a man of noble character. His mass killings and other crimes against humanity are honoured. Nothing illustrates this more than the Chiang Kai-shek Memorial. The memorial has become a symbol of the KMT's resistance against justice and dignity. It has created a country with two value systems. At the other end of the diametrically opposing value system we find the victims. The 2-28 Memorial Hall symbolizes their pain and suffering.

The glorification of the Chiang family turns criminals into heroes and dictators into fathers of democracy. Wu Nai-teh (Wu Nai-de), a sociologist at the Academia Sinica, appears to be one of the very, very few local scholars who have openly challenged the misconception that Chiang Ching-kuo initiated democracy in Taiwan. He notes in one of his papers that Chiang Ching-kuo was everything but favourable of democracy. ${ }^{31}$ According to $\mathrm{Wu}$, Chiang had a low regard for the rule of law and human rights. Moreover, he believes that Chiang's only contribution to Taiwan's democracy was that he had removed the main obstacle to democratisation, namely his own dictatorship. James

28 In this book, Irving argues that although the Nazi crimes occurred, Hitler had neither real or direct responsibility for what happened nor knowledge about it. His thesis was not shared by the international community and Irving was soon identified as "one of the most dangerous spokesmen" for the denial of the Nazi crimes. As I mentioned in the second part of this paper, Irving was later arrested in Austria for similar statements under the Prohibition Act and served a one-year prison term. Deborah, Lipstadt, Denying the Holocaust. The Growing Assault on Truth and Memory (New York: New York Free Press, 1993), 181.

29 The ad can be viewed at: http://www.eastasia.at/issue2/ad6.htm.

30 See Richard Lange, "Über das Denunziantenproblem," Süddeutsche Juristenzeitung (1948): 302-12; and Tiefenthaler, Denunziation.

31 Wu Nai-de, "Reformer or Dictator? Reassessing the Role of Chiang Ching-guo in the Democratic Transition" [huiyi jiangjingguo, huainian jianggingguo], Proceedings of the Seventh Conference of the National Archives (National Archives: Taipei, 2004), 467-502. 
Soong and the media consequently attacked Wu Nai-teh for his 'outrageous' criticism. They belittled the significance of Wu Nai-teh's statement by saying that he was seeking a position in the DPP government or that he just wanted to be famous. The most ignorant and unsophisticated analyses could naturally be found in Taiwan's print media. One commentary in the China Post, for example, expressed regret that Wu Nai-teh had used his academic expertise to serve political interests.

Joseph $\mathrm{Wu}$ (Wu Zhao-xie), former chair of the Mainland Affairs Council, could not be more right when he pointed out that a significant part of Taiwan's intellectuals suffers from the so-called Stockholm syndrome. Joseph Wu's interesting observation reminded me of the famous girl in box ${ }^{32}$ and writer Long Ying-tai's series of lectures called Saloon. In her Saloon lectures, Long Ying-tai usually elaborates on her historic mission to 'enlighten' the people of Taiwan. Her Saloon lecture series indeed covers a range of interesting topics that are scarcely discussed in Taiwan. ${ }^{33}$ However, her enlightenment tends to end up in pure KMT propaganda when Taiwan's political situation is discussed. During the lectures I attended, she showed her clear preference for the KMT leadership while strongly attacking Chen Shui-bian. In her view, Chen had caused enormous damage to Taiwan's society and economy. She vigorously defended her belief that Chen had provoked China with his policies. She may dislike Chen Shui-bian and his leadership style, but blindly adopting the opinions expressed by the KMT, and cheerfully supporting the leadership of the same organisation that has brutally killed millions of civilians has absolutely nothing to do with enlightenment. How can she deny and belittle the atrocities the KMT had committed? Does enlightenment mean writing newspaper commentaries that portray Chen Shui-bian as the only criminal and most disgraceful president in the entire history of the Republic of China? Isn't her statement a crime by itself? Aren't the systematic and widespread denial and belittlement also crimes against humanity? Isn't Lung Ying-tai with her statements an accessory to such crimes? How can Lung Ying-tai's foundation enlighten people when people like Nan Fang-shuo are among its board members? How could she support Nan Fang-shuo's endorsement of Huang Chi-hsian's book that describes Chen Shui-bian as Taiwan's Hitler? Where are the high intellectual standards she praises herself to be in possession of?

Enlightenment is the process of critically questioning the existing norms and traditions. Enlightenment is to assist the people in obtaining the ability to think critically and not to teach people what they should think. This concept was fully understood by the activists of the student movement of the early 1990s. Chen Hsin-hsing (Chen Xin-xing), one of participants, writes in an essay that the aim of the movement was not to attack the government and at the same time blindly support the opposition. ${ }^{34}$ On the contrary, the movement doubted the necessity of yet another leader the people should unquestioningly support. The movement believed in a society that was able to make its own decisions rather than in a society that has decisions forced upon by some leaders. ${ }^{35}$ The 1990 student movement reflected to the fullest extent the true meaning of enlightenment. Chen also notes that the movement failed to materialise their ideas. The so-called new student movement of 2004 and the Red Movement of 2006 have confirmed Chen's assessment. Both movements lacked the ability to question the motives of the elite and to question their own. They were mere puppets of elitist circles, the executioners of the same leadership group that had seized their ability to seriously

32 The girl in the box: About thirty years ago, a girl was abducted and held in captivity for seven years. During that time, she had to sleep in coffin-like box under the perpetrator's bed. She was consistently tortured and sexually abused to the point of complete mental and physical subservience. Whenever there was a chance to escape she would not run away. When the police found her she stated that she had lived in a consensual love relationship with the perpetrator. She objected the idea that she had been a victim. On the contrary, she was thankful to the perpetrator. The perpetrator himself denied any wrongdoing and stressed that he had only fatherly protected the girl.

33 The lectures are officially organized by her foundation (www.civictaipei.org).

34 Chen Xin-xing, "My Wild Lily: Self-Criticism of a Participant in the March 1990 Student Movement" [wode yebaihe - yige 1990 nian sanyue xueyundong canyu de wo piping], Taiwan: A Radical Quarterly in Social Studies, no. 54 (2004): 253-76.

35 Jürgen Habermas made the same conclusions in his critique of the left movement in Germany. 
question the nature and implications of their actions. The two movements have propelled Taiwan's society back to where it was at the beginning of the 1990s: No progress towards enlightenment in sight.

Furthermore, I do not have the impression that enlightenment is the aim of a growing number of Taiwan's intellectuals. The so-called new democracy movement, for example, has shown its preference for communitarian ideas over liberal values. The movement's emphasis on communitarian concepts is reflected in the writings of its leaders, such as Huang Kuang Kuo (Huang Guang-guo). ${ }^{36}$ The same criticism holds for several TV programme hosts, such as Sisy Chen (Chen Wen-qian), and politicians, such as Ma Ying-jeou, who glorify China and its leaders despite the fact that China has one of the world's worst human rights records. China's growing economic importance cannot be denied, but this does not mean that we have to look up to its dictatorial leaders and teach Taiwan's youth to become like Hu Jin-tao. Ma Ying-jeou's statement is distressing because it conveys the message that economic growth justifies inhumanity. ${ }^{37}$

Taiwan has over 150 institutions of higher education. One would assume that these institutions could assist in the attempt to enlighten Taiwan's society. But the Red Movement proved otherwise. The streets of Taipei were crowded with yelling people making thumbs-down gestures. The media, the KMT and other intellectuals spoke of a great moment in the nation's history. Justice would come soon, the unscrupulous, ferocious, corrupt president would soon be gone, and the great Republic of China would once again emerge on the horizon as to protect the people of Taiwan from all evils. The period of the Red Movement was a time of enormous intellectual discourse. University professors dressed in red showed their unlimited support for the new leader, the protector of the great Chinese nation. Half a million people dressed in red were said to have participated in protests on the streets of Taipei. The intellectual elite of the KMT, of course, was there too. After all, the participants could enjoy artistic performances while sharing free food and drinks. Everybody was curious to find out what would be next on the programme. Not only artists could perform there, intellectuals from all walks of life could express their opinion. Students joined the programme, too. Some of them repeated their leader's opinion that Chen was corrupt and should step down. Others were more intellectual and rephrased songs and poems. They seemed all to be extremely excited because they were live on TV. They were the heroes of a great revolution. The world would remember them as the true fighters for justice and democracy. It was simply in vogue to be on TV and to attack Chen Shui-bian. Even primary school kids learned their anti-Chen poems and presented them at school. One intellectual thought that it would be funny to disguise himself as Chiang Ching-kuo and publicly attack Chen Shui-bian. A few decades earlier, Shi Ming-teh had been a victim of the very same Chiang Ching-kuo. But as the leader of the Red Movement he now had to find Chiang Ching-kuo's appearance amusing. But who would take things too seriously? After all, it was only a carnival.

The Hong Kong weekly Yazhou Zhoukan reported extensively on the Red Movement. At the end of September, for instance, the magazine ran a cover story entitled 'Island of Sadness, Wave of Anger: Six Years President Chen and 16,000 Suicide Cases.' From the title of the story, the reader can easily grasp the motives of the journalist. He or she tries to compare the 2-28 Massacre with Chen Shui-bian's presidency. ${ }^{38}$ The story asserted that President Chen's policies had harmed Taiwan's society and economy. According to the author of the story, all of the 16,000 people who had committed suicide during President Chen's term had done so because of his policies. According to the story, Chen Shui-bian had thus 'killed' more people than the KMT government in the 2-28 Massacre. What a statement! As I quoted a Hong Kong weekly, people may think that such inhuman claims can only be found on the mainland, where the media is controlled by the Beijing government. But they are wrong. The same absurd statements are common occurrence in Taiwan. The Red

36 Huang Guang-guo, Populism and the End of Taiwan [mincui wang tai lun], second edition (Taipei: Cite, 1996).

37 I am inclined to think that the entire KMT leadership really believes in such a concept.

38 Island of Sadness (beiqing daoyu) should remind the reader of the famous film City of Sadness (beiqing chengshi) - a film about the 2-28 Massacre. 
Movement reflects the abrupt downward trend in Taiwan's intellectual discourse and the wellcoordinated attempt to diffuse the issue of transitional justice. The Red Movement was no coincidence. The attacks on Chen Shui-bian are part of an attempt to stigmatise those who ask for transitional justice. In the eyes of the KMT and its supporters Chen is an enemy because he points at the truth and by doing so he endangers their personal (economic) interests - interests in Taiwan as well as in Mainland China.

\section{Conclusion and Policy Suggestions}

In the first part of my paper, I have explained the legal consequences of the Nazi atrocities. We have learnt that the Austrian government passed several special laws as to deal with those crimes. The most important were the Prohibition Act and the War Criminal Act. The first was designed to prevent the re-occurrence of a Nazi state and to provide a legal framework under which Nazi crimes could be prosecuted. The latter law was necessary as existing laws either did not cover several crimes or their punishment appeared too lenient given the nature of the crimes.

In the second part of my paper, I looked at the current anti-Nazi legislation. We have learnt that the Nazis had been tried under the War Criminal Act until 1957. In that year, the government was of the opinion that after more than ten years of prosecution, the focus of their anti-Nazi efforts should shift from prosecution to prevention. The War Criminal Act was thus abolished, but the Prohibition Act not. As a matter of fact, it is still in force today. The belittlement, denial, justification and glorification of the crimes committed by the Nazis are criminal offences with the maximum sentence of life imprisonment. As I mentioned earlier, the law should prevent future crimes against humanity and it should give respect to the victims, especially to those who survived the terror of the regime. The Austrian government believes that it is inhuman to glorify and trivialize the NS atrocities in front of those who suffered and still suffer from the psychological and physical pain that had been caused by exactly these atrocities. Denial and belittlement do not contribute to a more human society. On the contrary, they bring us closer to those who committed the atrocities.

From the third part of the paper we have gathered that Chiang Kai-shek, Chiang Ching-guo and the KMT have committed crimes against millions of civilians on the mainland. In Taiwan, they have brutally killed tens of thousands of civilians and committed other crimes against humanity. Nevertheless, none of the perpetrators has been charged and tried under existing laws. As several legal theorists, such as Chen Chi-long (Chen Zhi-long) and Huang Mao-rong pointed out, the perpetrators could be tried for most of their crimes under the existing legal framework. ${ }^{39}$ But still there seems to be no interest in prosecuting the perpetrators. There are several minor reasons and one main reason for such a regrettable situation. The main reason is that the majority of the population either suffers from the Stockholm Syndrome or believes that the crimes were necessary and excusable. As I have pointed out in my paper, there are influential intellectuals who understand the seriousness of the crimes but still feel sympathetic to the perpetrators. As to the perpetrators themselves, the KMT leadership and its supporters have adopted two key strategies on how to deal with the crimes. The first involves denial, belittlement, glorification and even justification. A more recent approach is to accept the crimes as historical facts, but deny the involvement of the KMT and its leaders. The second key strategy is to stigmatize those who ask for justice. The activities of the Red Movement and the attacks on Wu Nai-teh and other scholars are examples here.

39 Chen Zhi-long, "The Legal Responsibility for 2-28 Massacre: Criminal Law" [ererba shijian tusha xingwei de xingshi falue zeren], in Report on The Responsibility for the 228 Massacre [ererba shijian zeren guishu yanjiu baogao] ed. Li Yan-xian, Yang Zhen-long and Zhang Yan-xian (Zhonghe: 228 Memorial Foundation, 2006), 491-533. Huang Mao-rong, "The Legal Responsibility for 2-28 Massacre: Civil Law” [ererba shijian zhi minshi zeren], in Report on The Responsibility for the 228 Massacre [ererba shijian zeren guishu yanjiu baogao] ed. Li Yan-Xian, Yang Zhen-long and Zhang Yan-xian. (Zhonghe: 228 Memorial Foundation, 2006), 535-51. 
As I pointed out earlier in this paper, the widespread and systematic denial and belittlement of the KMT crimes and the glorification of their prime perpetrators are crimes by themselves. I believe they constitute crimes against humanity under international law. ${ }^{40}$ Considering Taiwan's international status this fact is, however, only of theoretical value. Still, it shows the seriousness of such behaviour from a legal perspective.

Applying what I have mentioned earlier about the Austrian transitional justice system, I should like to propose eight normative measures that should help the victims of the KMT atrocities to obtain the dignity they deserve:

1) Dissolution of the KMT and all its related organizations

The KMT and its organizations have to be dissolved immediately. Their property must be transferred to the State.

2) Prohibition of re-establishment of the KMT and its related organizations

Any attempt to re-establish the KMT or any of its related organizations, contacting or financing such organizations, or producing propaganda material should be declared a criminal offence with a minimum prison sentence of ten years. If the offender or the action is particularly dangerous, the penalty should be life imprisonment.

3) Prohibition of glorification and denial of the crimes committed by Chiang Kai-shek, Chiang Ching-kuo, the Kuomintang and its related organizations

Anyone who denies, grossly trivializes, approves of or seeks to justify the KMT atrocities in a publication, broadcast or other media or in any other public manner accessible to others should face imprisonment between 1 and 10 years. If the offender or the action is particularly dangerous, the penalty should be life imprisonment.

4) Removal of all relics and symbols associated with the KMT dictatorship

All effigies of Chiang Kai-shek, Chiang Ching-kuo or other key leaders in the KMT movement should be banned. The same ban should be applied to symbols of the KMT, such as the party emblem.

5) Establishment of a special foundation

The foundation should be the main agency in dealing with issues related to transitional justice in Taiwan. Its major aim is to oversee the restitution of property and the compensation of victims, to finance research related to the KMT atrocities, to educate the general public about the KMT crimes against humanity and to promote preventive measures.

6) Prosecution of crimes against humanity committed during the Nationalist period

The perpetrators should be tried in accordance with existing laws. If necessary special laws should be enacted to deal with crimes against humanity as defined by international law.

7) Enforcement of compulsory atonement measures

Supporters of the KMT and its organisations should be separated into two groups. The first comprises those supporters who held key positions in the KMT or the government before 1987. The second group composes of those who held lower positions in the KMT or government hierarchy. Atonement measures for the first group of perpetrators should include a lifetime ban on holding government positions, the payment of a special tax for 5 years, and the confiscation of a considerable portion of the property they owned in 1987. They should also be barred from holding positions in universities and other educational institutions. Perpetrators of the second group should have to face lighter atonement measures.

8) Educational reform

40 The prosecution of inhuman acts such as the denial and belittlement of crimes against humanity has so far depended on national legislation. From a theoretical point of view, though, they could be considered crimes, namely crimes against humanity. Recent UN Resolution A/RES/61/255 condemning the denial of the Nazis crimes, recent legislation in a number of EU countries and the Rome Statute of the International Criminal Court have opened new channels of interpretations. 
History books and other educational material should clearly mention the atrocities committed by the KMT and its related organisations. Chiang Kai-shek, Chiang Ching-kuo and the KMT should be named as the prime perpetrators of the atrocities committed during their dictatorships.

Considering my analysis of Taiwan's intellectuals, none of these measures seems likely to be ever implemented, though. Notwithstanding, I do believe that it would be beneficial to Taiwan's society if the people of Taiwan could escape their mental imprisonment and opt for a more human society.

Numerous local scholars have criticised my approach as being 'not helpful' and 'inappropriate.' Why? Because they think the KMT is right when it points out that after all it was the KMT and its dictators who turned Taiwan into one of the world's largest economies. Without the KMT there would be no Taiwan. This view is echoed by a growing number of foreign scholars, especially by Anglo-Americans, and foreign journalists. In Taiwan as well as abroad, they have become the core defenders of the KMT atrocities. For example, on 28 February 2007, the sixtieth commemoration day of the 2-28 Massacre, I had the opportunity to exchange views regarding the KMT's dark past with a number of foreign journalists and academics. Most of them applauded the pro-Chiang commentaries they had read on the Internet or in local newspapers and told me that they had been particularly impressed with the following commentary printed in the English-edition of the China Post:

It was a nice Chinese New Year holiday, unusually long (nine days in a row), with good weather (not warm nor cold and mostly no rain), no newspaper for five days and most of the political talk dhows vanished from the screen. It was a rare tranquil time for family get-togethers and relaxation. Most gratifying of all, President Chen Shui-bian maintained a surprising low profile throughout the holiday, doing or saying little to irritate his enemies in Beijing, friends in Washington, or critics at home. But yesterday, the first day of work, Chen resumed his anti-China campaign by defaming the late President Chiang Kai-shek as the "prime culprit" of the infamous 1947 "2-28 Incident", which resulted in ten to thirty thousand civilians killed and Taiwan's governor executed. Chiang's rule began after his arrival in 1949. Tomorrow, the Chen-DPP government will hold various activities to mark the 60th anniversary of the tragedy, hoping to score points in an election year. Despite his authoritarian rule, Chiang is a shining symbol of the Republic of China. Without Chiang, there would be no Republic of China, and certainly no President Chen, nor prosperity, democracy and security for Taiwan today. Chen would be doing a big favour for Taiwan and himself if he kept his holiday low profile through his retirement on May 20, 2008. ${ }^{41}$ (41)

I believe that it does not make sense to link the KMT's atrocities and the superiority of the Mainland Chinese with Taiwan's prosperity. From a scientific point of view, there is neither any evidence that the Taiwanese are more stupid than the mainlanders, nor is there any evidence that there is a positive correlation between authoritarianism and economic prosperity. Even if there were such evidence, the belief that a superior race is obliged to rule others by any means (including the systematic and widespread torture and brutal killing of civilians) is inhuman and in violation of our highly praised values of freedom and democracy. Does eight or ten percent economic growth justify atrocities? Should we have a law allowing crimes against humanity based on a regime's economic performance?

Considering the Western euphoria about democracy and human rights, there simply is no logical reason why Western intellectuals defend the KMT and hold President Chen and his party in contempt. Western scholars tend to closely follow Taiwan's mainstream intellectuals and conse-

41 China Post (English edition), 'De-Chiang is anti-history,' 27 February 2007. 
quently find themselves trapped in the same illogical path of reasoning: We should not talk about the past and the atrocities committed by the KMT. Talking about such things is inappropriate, since such discussions would inevitably lead to political disorder if not even to civil war. People should not waste their time on such useless discussions; they should concentrate on the economy instead. Taiwan's economic situation has deteriorated under President Chen who has talked too much about the KMT's past. Only people who support Taiwan's independence talk about the KMT's dark history as to gain popular support at the polls. Taiwan should unify with China. It is good for Taiwan and good for everybody.

I have encountered local and Western scholars who claimed that other East Asian countries, such as South Korea, performed better in economic terms than Taiwan and pinned the blame for Taiwan's 'deteriorating economy' on President Chen's permanent 'irresponsible attacks' on the KMT. As a matter of fact, South Korea has established a truth commission to investigate and prosecute crimes against humanity committed by previous governments and there has not been any sign of an economic disaster because of it.

The truth is that the West lacks any logical reason (Erklärungsnotstand) for defending the KMT and tries to construct arguments that are designed to cover its ignorance and indifference.

\section{References}

Chen, Zhi-long (2006), 'The Legal Responsibility for 2-28 Massacre: Criminal Law' [ererba shijian tusha xingwei de xingshi falue zeren], in Report on The Responsibility for the 228 Massacre [ererba shijian zeren guishu yanjiu baogao] edited by Li Yan-hsian, Yang Zhen-long and Zhang Yan-xian. Zhonghe: 228 Memorial Foundation: 491-533.

Chen, Xin-xing (2004), 'My Wild Lily: Self-Criticism of a Participant in the March 1990 Student Movement' [wode yebaihe - yige 1990 nian sanyue xueyundong canyu de wo piping], Taiwan: A Radical Quarterly in Social Studies, no. 54: 253-76.

Encyclopaedia of Genocide and Crimes Against Humanity (2005), edited by Dinah L. Shelton, Thomson: Farmington Hills, MI.

Gallhuber, Heinrich and Eva Hopfer (2001), 'Die Einzelnen Bestimmungen des KVG,' Justiz und Erinnerungen, no. 4: 32-4.

Garscha R., Winfried (2000), 'Entnazifizierung und gerichtliche Ahndung von NS-Verbrechen,' in NS-Herrschaft in Österreich edited by Emmerich Talos, Ernst Hanisch, Wolfgang Neugebauer and Reinhard Sieder. Oebv: Wien, 852-83.

Halbrainer, Heimo (2006), 'Der Angeber musste vorhersehen, dass die Denunziation eine Gefahr für das Leben des Betroffenen nach sich ziehen werde,' in Holocaust und Kriegsverbrechen vor Gericht edited by Thomas Albrich, Winfried R. Garscha and Martin F. Polaschek. Innsbruck: Studienverlag.

Huang, Guang-guo (1996), Populism and the End of Taiwan [mincui wang tai lun], 2nd edition. Taipei: Cite.

Huang, Guang-guo (2004), Populism and the End of Taiwan: A Chronology [mingcui wang tai ji]. Taipei: Democratic Action Alliance.

Huang, Zhi-xian (2004), Shuddering Future: Dismantle Taiwan's New Dictatorship [zhanli de weilai: jiegou taiwan xin ducai], revised edition. Taipei: Miluo.

Huang, Mao-rong (2006), 'The Legal Responsibility for 2-28 Massacre: Civil Law' [ererba shijian zhi minshi zeren], in Report on The Responsibility for the 228 Massacre [ererba shijian zeren guishu yanjiu baogao] edited by Li Yan-xian, Yang Zhen-long and Zhang Yan-xian. Zhonghe: 228 Memorial Foundation: 535-51. 
Lange, Richard (1948), 'Über das Denunziantenproblem,' Süddeutsche Juristenzeitung (1948): 30212.

Li, Yan-Xian, Yang Zhen-long and Zhang Yan-xian ed. (2006), Report on The Responsibility for the 228 Massacre [ererba shijian zeren guishu yanjiu baogao]. Zhonghe: 228 Memorial Foundation.

Lipstadt, Deborah (1993), Denying the Holocaust. The Growing Assault on Truth and Memory. New York: New York Free Press.

Mueller, Felix (2005), Das Verbotsgesetz im Spannungsverhältnis zur Meinungsfreiheit: Eine Verfassungsrechtliche Untersuchung, Wien: Verlag Österreich.

Rummel, R. J. (1994), Death by Government, Transaction: New Brunswick.

Stiefel, Dieter (1981), Entnazifizierung in Österreich, Wien: Europaverlag.

Tiefenthaler, Guido (1995), Denunziation während der NS Herrschaft im Spiegel der Volksgerichtsprozesse, Universität Wien, Diplomarbeit.

Wu, Nai-de (2004), 'Reformer or Dictator? Reassessing the Role of Chiang Ching-guo in the Democratic Transition' [huiyi jiangjingguo, huainian jianggingguo], Proceedings of the Seventh Conference of the National Archives: Taipei, 467-502. 